Cell Tissue Kinet. (1972) 5, 467-479.

\title{
MOBILIZATION OF HAEMOPOIETIC STEM CELLS (CFU) INTO THE PERIPHERAL BLOOD OF THE MOUSE; EFFECTS OF ENDOTOXIN AND OTHER COMPOUNDS
}

\author{
O. Vos, W. A. Buurman and R. E. Ploemacher \\ Medical Biological Laboratory TNO, Lange Kleiweg 139, Rijswijk (Z.H.), \\ and Department of Cell Biology and Genetics, Rotterdam Medical Faculty, \\ The Netherlands
}

(Received 14 April 1972, revision received 15 June 1972)

\begin{abstract}
Factors affecting the circulation of haemopoietic stem cells (CFU) in the peripheral blood of mice were investigated. I.v. injection of sublethal doses of endotoxin, trypsin and proteinase appeared to raise the number of CFU per ml blood from about $30-40$ to about $300-400$ or more within $10 \mathrm{~min}$. The effect was smaller when smaller doses of the substances were injected. After this initial rise the number of circulating cells returned to normal in a few hours. Following endotoxin there was a second rise which started 2-3 days after injection and attained a peak on the 6th-7th day. The first rise is explained as a mobilization of stem cells from their normal microenvironments into the blood stream; the second rise is considered to reflect proliferation of CFUs in the haemopoietic tissues. The spleen seems to be acting as an organ capturing CFUs from the blood and not as a source adding stem cells to the blood.

The early mobilization of CFU after endotoxin injection did not coincide with a mobilization of neutrophils. The number of circulating band cells was increased during the first hours.

The importance of 'open sites' in the haemopoietic tissue for capturing CFUs was studied by emptying these sites through a lethal $\mathrm{X}$-irradiation and injecting normal bone marrow cells. When a greater number of syngeneic bone marrow cells was injected intravenously, the level of circulating CFU in irradiated mice was slightly lower than the level in unirradiated mice during the first hours.
\end{abstract}

\section{INTRODUCTION}

For several years it has been known that haemopoietic stem cells can be present in the peripheral blood of the mouse. Experimental evidence for the existence of circulating stem cells has been provided by Goodman \& Hodgson (1962). These authors were able to promote

Correspondence: Dr O. Vos, Department of Cell Biology and Genetics, Rotterdam Medical Faculty, Dr Molewaterplein 50, Rotterdam, The Netherlands. 
survival of lethally irradiated mice by injection of leucocytes from blood of normal donors and they could demonstrate that donor-type erythrocytes and granulocytes were produced in long-term survivors. More direct evidence for circulating stem cells was given by Hanks (1964), Hellman (1965) and Robinson, Commerford \& Bateman (1965). In these publications a migration of stem cells from shielded bone marrow towards the spleen was described. Homing of these migrating cells in the spleen could be demonstrated with the endogenous spleen colony technique. Hellman \& Grate (1968) observed that an initial rapid migration from the shielded marrow was followed by a slower outflow and they interpreted their findings 'as evidence of there being in the marrow a small pool of colony forming units having easy access to the blood'. They postulated that in addition to the 'small pool of colony-forming units having rapid interchange between blood and bone marrow' there was a slow release of cells from a bound bone marrow stem cell pool.

Barnes \& Loutit (1967a) and Hellman \& Grate (1968) determined that $1 \mathrm{ml}$ of peripheral blood of a normal mouse contains about 10-30 colony forming units (CFU). Although variations in the level of circulating CFU before (Barker, 1970) and after birth (Barnes \& Loutit, 1967b) have been described and substances affecting the number of circulating stem cells have been published (Barnes \& Loutit, 1967a, b), little is known about the dynamics and the regulatory mechanism for stem cell circulation and migration. Fliedner (personal communication) has made the suggestion that stem cells for bone marrow transplantation might be obtained from peripheral blood with an IBM cell separator. In this way bone marrow puncture of the donor could be avoided. Since the number of stem cells in the blood is low, an elevation of the level of circulating cells would improve the applicability of such a procedure.

In the present paper fluctuations in the level of circulating CFU after injection of endotoxin and other substances will be described. The observations will be discussed in relation to dynamics of the stem cell pool and the mechanisms which may regulate it.

\section{MATERIALS AND METHODS}

Male and virgin female $\mathrm{CBA} / \mathrm{Rij}$ and $\mathrm{F}_{1}(\mathrm{C} 57 \mathrm{BL} / \mathrm{Rij} \times \mathrm{CBA} / \mathrm{Rij})$ mice were used. Mice employed as donors were 10-16 weeks old in all experiments. $F_{1}$ male recipients were 10-16 weeks, $F_{1}$ females 4-8 months and CBA male or female recipients 4-10 months old. Weights varied between 20 and $32 \mathrm{~g}$. X-irradiation was performed with a $250 \mathrm{kV}$ Philips X-ray machine; physical constants and other radiation details are described in a previous publication (Vos, 1967). CBA and $F_{1}$ recipient mice were irradiated with a lethal dose of 770 and $825 \mathrm{rad}$ respectively. These lethal doses were different because in former experiments it had been shown that $\mathrm{F}_{1}$ mice were slightly more resistant to $\mathrm{X}$-irradiation than CBA mice.

Salmonella typhosa and Escherichia coli endotoxin (Bacto-lipopolysaccharide prepared by the Boivin method) solutions were made in Tyrode shortly before use. When not further specified in the text endotoxin from S. typhosa was used. Similarly proteinase (crystalline bacterial proteinase, Novo Industry A/s Copenhagen, Denmark), trypsin ( $1: 300$, Nutritional Biochemicals Corporation) and other solutions were made shortly before injection. $0.5 \mathrm{ml}$ of a solution was injected into the tail vein or intraperitoneally.

Each blood sample used for the CFU assay was obtained from the suborbital plexus of three ether anaesthetized mice. $2.5 \mathrm{ml}$ blood was collected in calibrated glass tubes containing $10 \mathrm{ml}$ Tyrode. Clotting was prevented by adding $5 \mathrm{IU}$ heparin to the Tyrode. If necessary the 
blood sample was further diluted with Tyrode before it was injected into the tail vein of a lethally irradiated recipient. The dilution which was injected contained 2-20 spleen colony forming cells per $0.5 \mathrm{ml}$. The correct dilution was estimated from results obtained in previously performed pilot experiments. From each blood sample two dilutions differing with a factor of 2 in blood concentration were made and $0.5 \mathrm{ml}$ of each dilution was injected into ten recipients. Hence the number of CFU per $\mathrm{ml}$ blood of each sample was measured by counting colonies in spleens of twenty recipient mice.

Blood used for leucocyte counts was obtained from the suborbital plexus. For each leucocyte count another mouse was used. The total number of white blood cells was determined with a Model B Coulter electronic particle counter. The percentage of neutrophil granulocytes was determined in May Grünwald-Giemsa stained blood smears.

Bone marrow and spleen cell suspensions were made as described earlier (Vos, 1967). Liver and lung suspensions were made in a similar way as spleen suspensions. The organs were cut in small pieces with scissors and mashed through a nylon sieve. Three dilutions of each suspension were made and $0.5 \mathrm{ml}$ of each dilution was injected into the tail vein of ten mice.

Cell suspensions from blood, bone marrow or other organs were injected within a few hours after irradiation of the recipients. For lung and liver suspensions the maximal amount which could be injected was often restricted by the occurrence of death from embolism in the injected mice.

The spleens were removed 8 days after injection and fixed in Bouin's fluid. Colonies were counted under the low power objective of a stereomicroscope.

Splenectomy was performed under Nembutal anaesthesia. Sham-splenectomized mice were treated exactly as splenectomized mice, except for the removal of the spleen.

\section{RESULTS}

Mice receiving $500 \mu \mathrm{g}$ endotoxin i.v. were shivering and showed a ruffled fur for several hours, but no mortality was observed. Injection of 100 or $50 \mu \mathrm{g}$ caused a similar effect, but

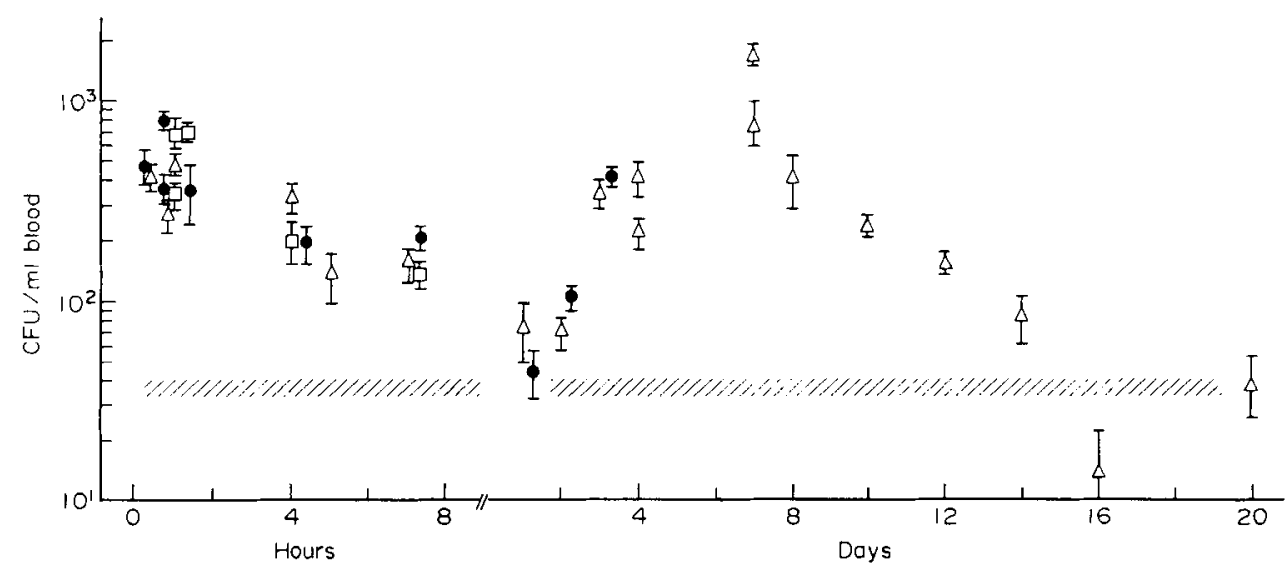

FIG. 1. Effect of an i.v. injection of $500 \mu \mathrm{g}$ endotoxin on the number of circulating CFU. $\triangle \mathrm{F}_{1}$ female, $\square$ CBA male and $F_{1}$ male mice; $95 \%$ confidence limits are indicated; the hatched area represents the level of circulating CFU in normal mice (mean \pm standard error). 


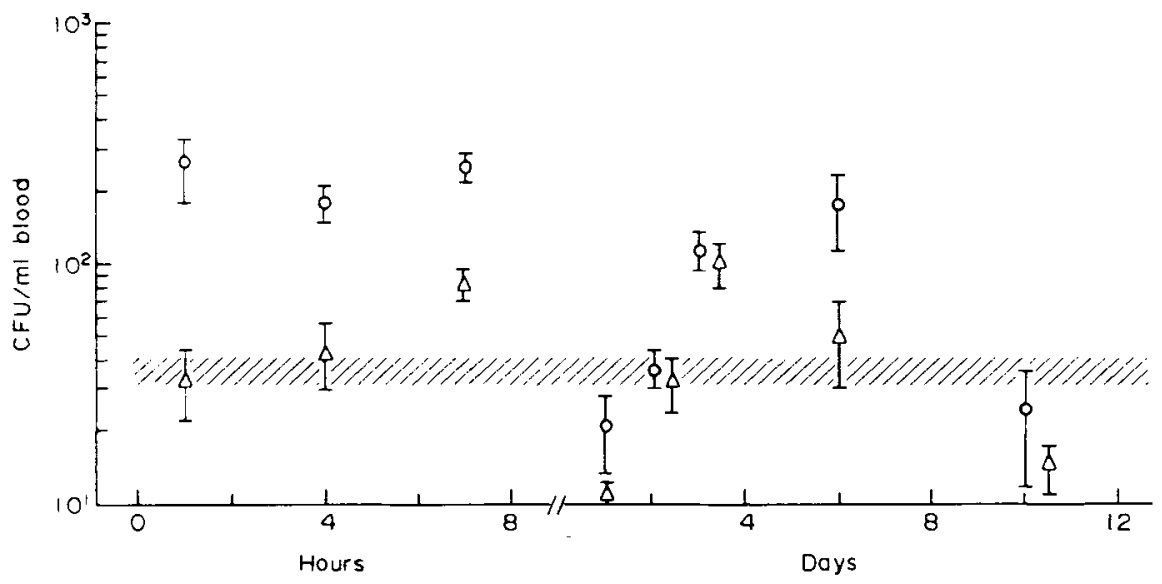

Fig. 2. Effect of i.v. injection of 100 and of $10 \mu \mathrm{g}$ on the number of circulating CFU. $0,100 \mu \mathrm{g}$; ,$- 10 \mu \mathrm{g}$. CBA male mice were used; $95 \%$ confidence limits are indicated; the hatched area represents the level of circulating CFU in normal mice (mean \pm standard error).

the symptoms were less pronounced. After $10 \mu \mathrm{g}$ no obvious signs of toxicity were noted. I.v. injection of $500 \mu \mathrm{g}$ endotoxin induced a biphasic increase in the number of circulating CFUs (Fig. 1). An initial rise starting within 10 min reached a peak around $1 \mathrm{hr}$ after injection. Subsequently the number of circulating CFUs slowly decreased. At $7 \mathrm{hr}$ after injection the level was still elevated, but after 1 day it was back to normal. At the second day the number of circulating CFU started to rise again and around the 7th day a second peak was observed. This second rise slowly decreased during subsequent days and the number was back to normal at 15-16 days after injection. After i.v. injection of $100 \mu \mathrm{g}$ a similar but less pronounced biphasic rise was found and after $10 \mu \mathrm{g}$ only at $7 \mathrm{hr}$ and 3 days a value above the normal level was observed (Fig. 2). Endotoxin from E. coli used in the same doses as endo-

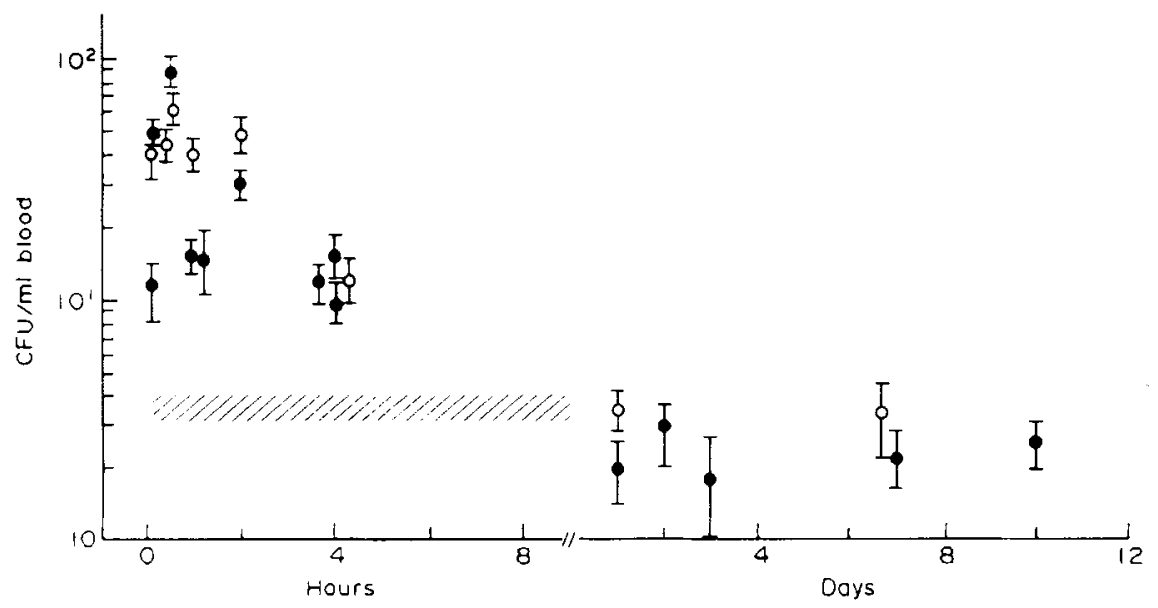

FiG. 3. Effect of i.v. injection of $2 \mathrm{mg}$ trypsin or $0.5 \mathrm{mg}$ proteinase on the number of circulating CFU. Proteinase:... trypsin. Female $F_{1}$ mice were used: $95 \%$ confidence limits are indicated; the hatched area represents the level of circulating CFU in normal mice (mean \pm standard error). 
toxin from $S$. typhosa produced comparable effects. When endotoxin was injected i.p. no increase in number of circulating CFU was found during the first $8 \mathrm{hr}$ after injection, but the second rise was found as after i.v. injection.

No mortality nor visible signs of altered behaviour of the mice were observed after injection of $2 \mathrm{mg}$ trypsin or $0.5 \mathrm{mg}$ proteinase into the tail vein. Both proteinase and trypsin elicited a rise of the number of $\mathrm{CFU} / \mathrm{ml}$ blood within $10 \mathrm{~min}$ after injection. A second rise as observed after endotoxin injection was not found with the proteolytic enzymes (Fig. 3). When lower doses of trypsin on proteinase were used the height of the rise decreased (Table 1). More purified trypsin $(2 \times$ crystallized beef pancreas trypsin and crystallized diphenylcarbamyl chloride treated beef pancreas trypsin, both from Nutr. Biochem. Corp.) was less

TABLE 1. Number of CFUs per $\mathrm{ml}$ blood $10 \mathrm{~min}$ after i.v. injection of various doses of trypsin or proteinase*

\begin{tabular}{ccl}
\hline Dose (mg) & Trypsin & \multicolumn{1}{c}{ Proteinase } \\
\hline 1.5 & $543( \pm 43)$ & \\
1.0 & $461( \pm 24)$ & \\
0.5 & $183( \pm 11)$ & \\
$0 \cdot 4$ & $60( \pm 5)$ & $369( \pm 25)$ \\
0.2 & $56( \pm 8)$ & $436( \pm 47)$ \\
0.1 & $56( \pm 7)$ & $482( \pm 32) ; 473( \pm 15)$ \\
0.04 & & $343( \pm 20)$ \\
0.02 & & $107( \pm 13)$ \\
0.01 & & $46( \pm 7)$ \\
\hline
\end{tabular}

* Mean numbers \pm standard errors are presented; female $F_{1}$ mice were used.

active than the trypsin which was routinely used. DFP inhibited trypsin (trypsin, $2 \times$ cryst., DFP from Nutr. Biochem. Corp.) still showed activity. The effect of a number of other compounds on the circulation of CFU within a few hours after injection was investigated, but no pronounced changes were observed. Versene $(0.8 \mathrm{mg})$, hyaluronidase (75 IU), collagenase $(0.2 \mathrm{mg})$, pronase $(0.5 \mathrm{mg})$, histamine $(5 \mathrm{mg})$ and noradrenalin $(0.05 \mathrm{mg})$ produced no significant alterations; heparin produced only a rise to about $100 \mathrm{CFU} / \mathrm{ml}$ blood 0.5 and $2 \mathrm{hr}$ after injection of a very high dose (25,000 IU).

It seems possible that shortly after injection of the effective substances high concentrations remain in the peripheral blood. Hence blood collected from mice shortly after injection might still contain great amounts of endotoxin or proteolytic enzymes. Since it could be argued that these compounds affect the colony formation by the CFU injected into the irradiated recipients or endogenous colony formation in the lethally irradiated mice, the compounds were dissolved in normal blood and the combination of blood and the compounds was injected. The results presented in Table 2 demonstrate that no effect on injected CFU or on endogenous CFU in the irradiated recipients could be observed.

The effect of an i.v. injection of $500 \mu \mathrm{g}$ endotoxin on the circulation of leucocytes is presented in Fig. 4. One hour after injection a fall in number of all cell types except juvenile neutrophil granulocytes (bands) could be observed. The number of lymphocytes stayed below normal during the whole period of observation. The number of band remained high 
TABLE 2. Number of CFUs per $\mathrm{ml}$ blood determined after injection of blood to which various doses of endotoxin or proteinase were added (female CBA mice were used)

\begin{tabular}{|c|c|c|c|}
\hline \multicolumn{2}{|c|}{ Doses injected } & \multicolumn{2}{|c|}{$\begin{array}{l}\text { Spleen colonies* } 8 \text { days } \\
\text { after injection of } \\
\text { blood containing: }\end{array}$} \\
\hline Compound $(\mu \mathrm{g})$ & Blood (ml) & Endotoxin & Proteinase \\
\hline- & 0.1 & $23(t 4)$ & $25( \pm 5)$ \\
\hline 500 & 0.1 & $33(t .8)$ & \\
\hline 250 & 0.05 & $38( \pm 9)$ & \\
\hline 20 & $0 \cdot 1$ & $24( \pm 4)$ & $27( \pm 6)$ \\
\hline 10 & 0.05 & $42( \pm 11)$ & $44( \pm 14)$ \\
\hline 4 & $0 \cdot 1$ & $27(+5)$ & $30( \pm 5)$ \\
\hline 2 & 0.05 & $20( \pm 6)$ & $56(\ldots 6)$ \\
\hline 1 & $0 \cdot 1$ & $36(-5)$ & $43( \pm 8)$ \\
\hline 0.5 & 0.05 & $32( \pm 8)$ & $44( \pm 8)$ \\
\hline
\end{tabular}

* Mean numbers $\rightarrow$ standard errors are presented.

during the first hours, but decreased in successive days. The total number of white blood cells attained a normal value on the 7 th day. This peak was mainly due to a high level of the neutrophils being 5 times above normal on this day. The peak in number of circulating neutrophils on the 7 th day occurred simultaneously with the peak in number of circulating CFU (Fig. 1).

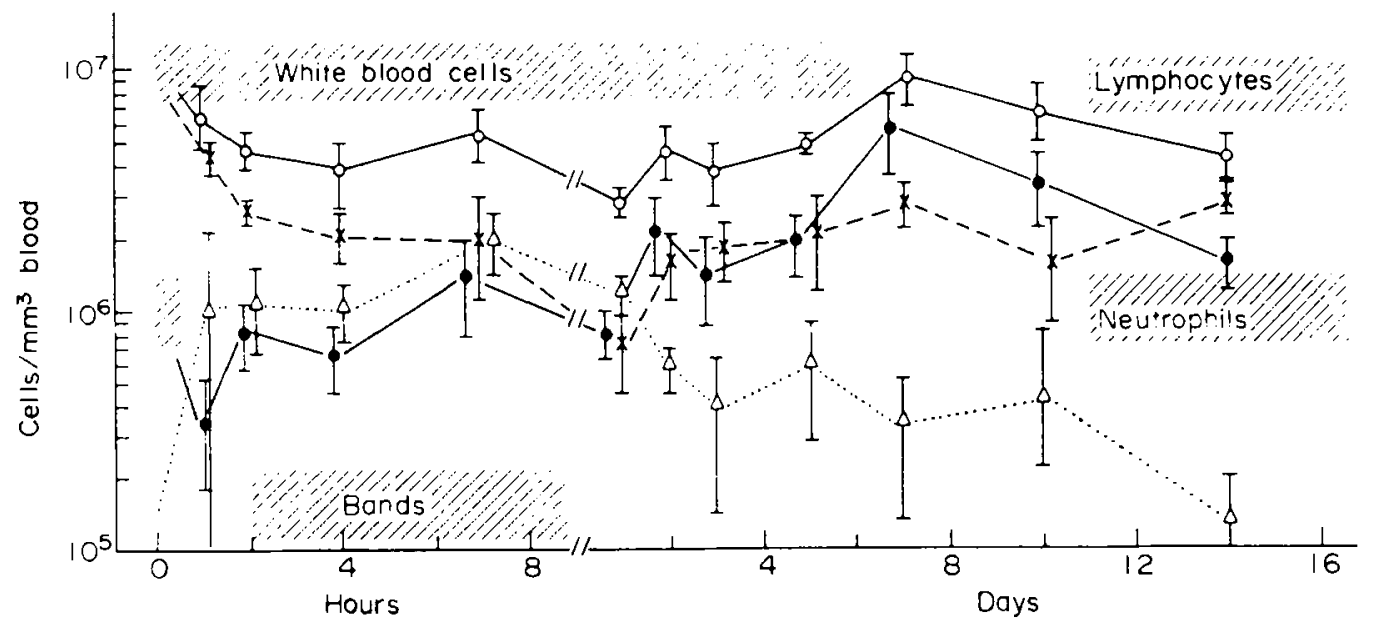

FIG. 4. Levels of total number of white blood cells, neutrophils, bands and lymphocytes after i.v. injection of $500 \mu \mathrm{g}$ endotoxin. C, Total number of white blood cells; $\bullet$, neutrophils; $\Delta$, band; $\nsim$, lymphocytes; standard errors are indicated; hatched areas show normal levels (mean - standard error) of respective cells. Male $F_{1}$ mice were used. 
TABLE 3. Circulation of CFUs in splenectomized mice after i.v. injection of endotoxin or proteinase*

\begin{tabular}{|c|c|c|c|c|c|}
\hline Mice & $\begin{array}{c}\text { Days after } \\
\text { operation }\end{array}$ & Injection & $\begin{array}{l}\text { Time after } \\
\text { injection }\end{array}$ & Sham-splenectomy & Splenectomy \\
\hline$F_{1} 00$ & $\begin{array}{l}15 \\
15 \\
42\end{array}$ & $0.1 \mathrm{mg}$ proteinase & $\overline{1 \mathrm{hr}}$ & $\begin{array}{r}31( \pm 7) \\
113( \pm 11) \\
29( \pm 5)\end{array}$ & $\begin{array}{r}85( \pm 11) \\
202( \pm 14) \\
99( \pm 7)\end{array}$ \\
\hline CBA & $\begin{array}{l}15 \\
15 \\
18 \\
18 \\
18 \\
19 \\
20\end{array}$ & $\begin{array}{l}0.5 \mathrm{mg} \text { endotoxin } \\
0.5 \mathrm{mg} \text { endotoxin } \\
0.5 \mathrm{mg} \text { endotoxin } \\
0.5 \mathrm{mg} \text { endotoxin } \\
0.5 \mathrm{mg} \text { endotoxin }\end{array}$ & $\begin{array}{l}1 \overline{\mathrm{hr}} \\
\overline{-} \\
1 \mathrm{hr} \\
7 \mathrm{hr} \\
1 \mathrm{day} \\
2 \text { days }\end{array}$ & $\begin{array}{r}382( \pm 14) \\
34( \pm 5)\end{array}$ & $\begin{array}{r}62( \pm 10) \\
616( \pm 76) \\
31( \pm 4) \\
912( \pm 78) \\
414( \pm 20) \\
150( \pm 13) \\
284( \pm 12)\end{array}$ \\
\hline CBA 우유 & $\begin{array}{l}34 \\
34 \\
34\end{array}$ & $\begin{array}{c}-\overline{-} \\
36 \times 10^{6} \text { b.m. cells } \\
36 \times 10^{6} \text { b.m. cells }\end{array}$ & $\begin{array}{l}1 \overline{\mathrm{hr}} \\
4 \mathrm{hr}\end{array}$ & $\begin{array}{r}33( \pm 6) \\
336( \pm 36) \\
82( \pm 9)\end{array}$ & $\begin{array}{r}54( \pm 5) \\
536( \pm 37) \\
230( \pm 11)\end{array}$ \\
\hline
\end{tabular}

* Figures represent mean numbers of CFU per ml blood; in parentheses: standard errors.

With respect to the elevated numbers of circulating CFU the question arises from which part of the haemopoietic system the CFU are mobilized and towards which part they are migrating. The role of the spleen was investigated by studying circulation and mobilization in splenectomized mice. In Table 3 the results of a few experiments are presented. It appears that in sham-splenectomized mice the level of CFUs per ml blood is similar to that in normal mice, whereas in splenectomized mice it is mostly raised above the normal level. After CFU mobilization by endotoxin or proteinase injections the level attained in splenectomized mice is similarly increased above that in sham-splenectomized mice. Also after injection of a great number of bone marrow cells, the number of circulating CFU diminished more

TABLE 4. CFU content of femoral bone marrow, spleen and blood after i.v. injection of

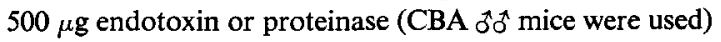

\begin{tabular}{ccccc}
\hline Experiment* & $\begin{array}{c}\text { Hours after } \\
\text { injection }\end{array}$ & ml blood & $\begin{array}{c}\text { No. of CFU† per: } \\
\text { spleen }\end{array}$ & femur \\
\hline 1 & - & & $2820( \pm 393)$ & $11000( \pm 817)$ \\
& 1 & & $2645( \pm 344)$ & $7600( \pm 980)$ \\
2 & 4 & & $5270( \pm 576)$ & $13500( \pm 1335)$ \\
& - & $24( \pm 5)$ & $600( \pm 195)$ & $9300( \pm 1410)$ \\
& 1 & $344( \pm 23)$ & $3250( \pm 415)$ & $9400( \pm 430)$ \\
& 4 & $178( \pm 22)$ & $3450( \pm 670)$ & $7300( \pm 760)$ \\
3 & 7 & $236( \pm 10)$ & $5750( \pm 385)$ & $7300( \pm 1280)$ \\
& - & $54( \pm 6)$ & $1500( \pm 235)$ & $12000( \pm 840)$ \\
& 1 & $>200$ & $2050( \pm 330)$ & $8700( \pm 1690)$ \\
& 4 & $119( \pm 10)$ & $3950( \pm 345)$ & $10200( \pm 1040)$ \\
\hline
\end{tabular}

* In experiments 1 and 2 endotoxin, and in experiment 3 proteinase was injected. + Standard errors are indicated in parentheses. 


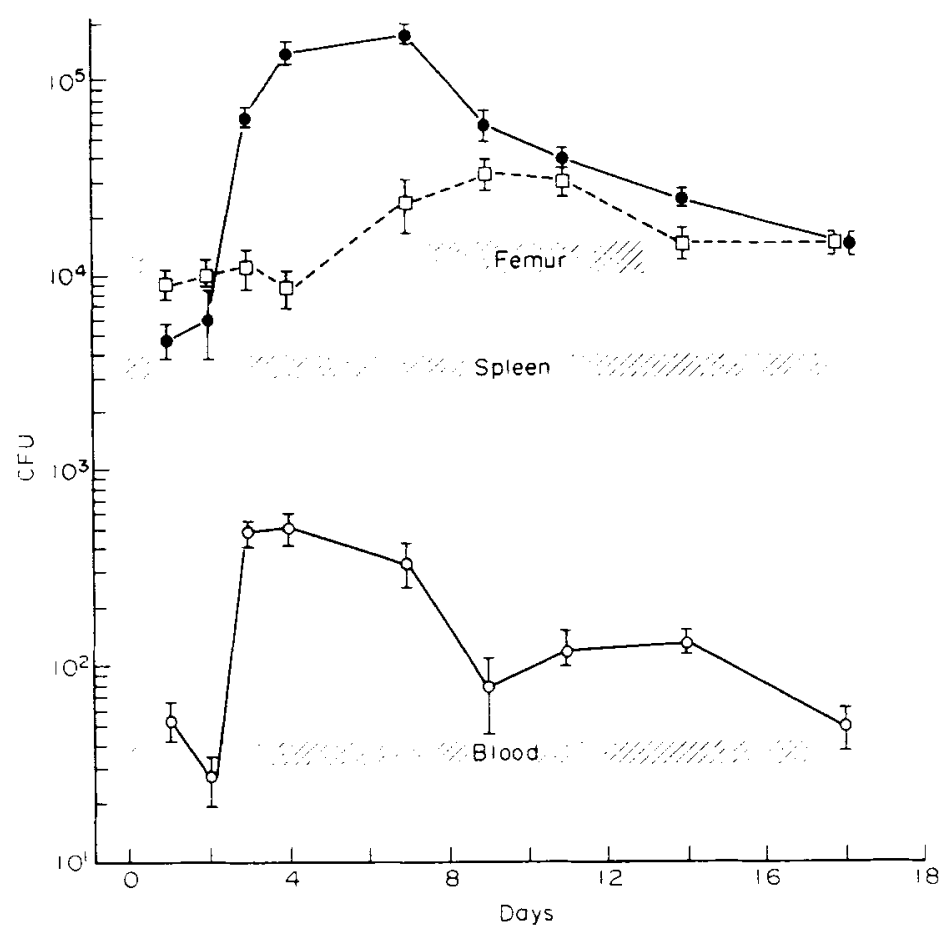

FIG. 5. Number of CFU in spleen, femoral bone marrow and $1 \mathrm{ml}$ blood at various times after injection of $500 \mu \mathrm{g}$ endotoxin. Spleen; $\sqsubset$, femur; $\sigma$, blood; $95 \%$ confidence limits are indicated, hatched areas show the normal level in spleen, femur and blood (mean \pm standard error). Male $F_{1}$ mice were used.

rapidly in sham-splenectomized than in spelenectomized mice. The migration pattern of CFU during the first hours was further studied by determining the number of CFU in femoral bone marrow and spleen at various times after endotoxin injection. The results shown in Table 4 indicate that although there is some scattering in the data, the number of CFU in the spleen tends to rise during the first hours after injection. The variations in the marrow are difficult to interpret. Multiplication of CFU during the first hours after endotoxin injection is not very likely. However, multiplication does play a role in the changes during the following days after injection. Fig. 5 illustrates the changes in spleen, bone marrow and blood. It appears that the peak of the number of circulating CFU is coinciding with a peak in CFU number in the spleen. The increase in number of CFU in the femur is less pronounced and comes a few days later than the increase in the spleen. The magnitude of this rise in the spleen is about 50 -fold.

A possible relation between the number of circulating CFU and 'open niches' for stem cells available in the haemopoietic tissues was studied by injecting bone marrow cells in normal and in lethally irradiated mice (Fig. 6). The circulation of injected CFUs seemed to be only slightly affected by the fact whether the recipient had been irradiated or not. In both groups of recipients high levels of $\mathrm{CFU} / \mathrm{ml}$ blood were found during the first 2-3 hr after injection. Although many data of the two groups, when they are compared point for point, are not significantly different, practically all the measurements in the irradiated mice show 


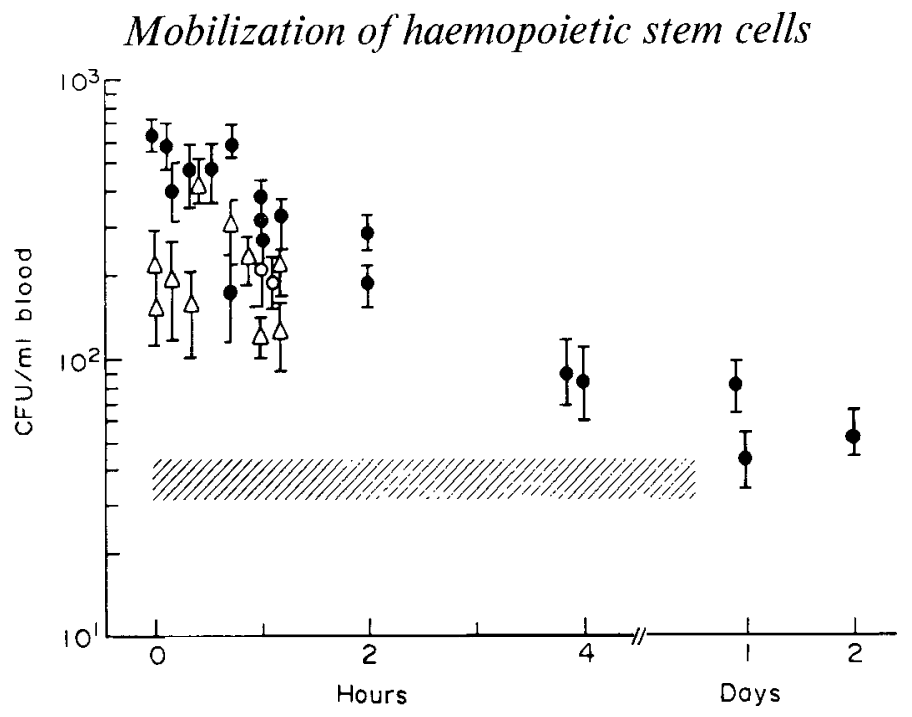

FIG. 6. Numbers of CFU in blood at various times after injection of $40 \times 10^{6}$ bone marrow cells in normal and in lethally irradiated mice. Male $F_{1}$ mice were used; $\bullet$, unirradiated recipients; $O$, recipients irradiated $2-3 \mathrm{hr}$ before injection; $\Delta$, recipients irradiated $2-3$ days before injection; $95 \%$ confidence limits are indicated; the hatched area represents the numbers in normal mice (mean \pm standard error).

lower levels than in the unirradiated mice. The number of CFUs which could be recovered from the blood in all mice was very low in comparison to the number injected. For this reason the CFU content shortly after bone marrow injection in other organs was also investigated. The numbers of CFUs in liver, lung and spleen are presented in Table 5. The data show that shortly after injection the number of CFUs in liver, lung and spleen is increased. The greatest increase is found in the liver.

TABLE 5. Number of CFUs recovered from liver, lung or spleen after i.v. injection of $40 \times 10^{6}$ bone marrow cells

\begin{tabular}{|c|c|c|c|c|}
\hline & \multicolumn{2}{|c|}{ No bone marrow injection } & \multicolumn{2}{|c|}{ Bone marrow injection } \\
\hline & $\begin{array}{l}\text { Recipient } \\
\text { irradiated }\end{array}$ & $\begin{array}{c}\text { Recipient } \\
\text { not-irradiated }\end{array}$ & $\begin{array}{l}\text { Recipient } \\
\text { irradiated }\end{array}$ & $\begin{array}{c}\text { Recipient } \\
\text { not-irradiated }\end{array}$ \\
\hline \multirow[t]{2}{*}{ Liver } & & $48( \pm 26)$ & \multicolumn{2}{|r|}{$1306( \pm 156)$} \\
\hline & & $40( \pm 14)$ & \multicolumn{2}{|r|}{$1750( \pm 160)$} \\
\hline \multirow[t]{2}{*}{ Lung } & & $13( \pm 9)$ & \multicolumn{2}{|r|}{$100( \pm 22)$} \\
\hline & & $7( \pm 7)$ & \multicolumn{2}{|r|}{$177( \pm 49)$} \\
\hline Spleen & 0 & $4143( \pm 284)$ & $157( \pm 16)$ & $6172(+447)$ \\
\hline
\end{tabular}

The numbers represent mean number of CFU per organ recovered 5 min after injection of bone marrow cells; in parentheses: standard errors; the figures marked with an asterisk are attained $1 \mathrm{hr}$ after injection of bone marrow; male $F_{1}$ mice were used. 


\section{DISCUSSION}

It seems unlikely that the increase in number of circulating CFU during the first hours after injection of endotoxin, trypsin or proteinase is caused by an increase in the total pool of CFU in the body; the time span between injection and the rise is too short for a cellular multiplication. Hence mobilization of stem cells from existing pools must be involved. These pools are probably localized in the haemopoietic tissues. The level of circulating CFUs in the blood of splenectomized mice before and after endotoxin injection suggests that the main pool is not localized in the spleen. The experiments in which the number of CFUs in spleen and bone marrow are determined a few hours after endotoxin or proteolytic enzyme injection indicate that the migration towards the spleen is greater than the migration out of it. Hanks \& Ainsworth (1967) described that the rate of migration of CFUs to the spleen was increased during the first hours after injection of endotoxin ( $50 \mu \mathrm{g}$ Piromen) in partial body irradiated mice.

It is improbable that great numbers of stem cells can be mobilized from marginal pools in blood capillaries as has been described for granulocytes (Athens et al., 1961) in man. The early mobilization of CFU after administration of high doses of endotoxin as has been described in the present paper was found to be non-correlated with a possible mobilization of granulocytes. During the increase of circulating CFUs the number of circulating neutrophils was decreased. Lower doses of endotoxin which are often described to cause a granulocytosis a few hours after i.p. injection (Smith, Alderman \& Cornfield, 1961; Smith \& Alderman, 1962) were ineffective in causing an increase in circulating CFU in our experiments. This indicates that the mobilization of granulocytes a few hours after i.p. injection of endotoxin is based on a different mechanism than the mobilization of CFUs almost immediately after i.v. injection. The finding of an early mobilization of immature granulocytes suggests that the i.v. injection of high doses of endotoxin causes changes in the bone marrow resulting in mobilization of cells. The number of cells involved in the rise of the CFUs into the peripheral blood and also in the migration to the spleen is in comparison to the total number of CFUs in the bone marrow of a relatively small magnitude. Hence a decrease of CFUs in bone marrow will be difficult to demonstrate.

It is not clear by which mode of action endotoxin and the other active compounds cause the mobilization of stem cells out of their pools. Changes in micro-environments may be considered, but it seems unlikely that the enzymes induce such changes through their proteolytic action. Immediately after injection the enzymes are facing so much protein in the blood that an action on the micro-environment of the stem cells is a remote possibility. Preincubation of trypsin with serum during $1 \mathrm{hr}$ at $37^{\circ} \mathrm{C}$ did not inhibit its activity (unpublished results). Contamination of trypsin (and proteinase) with another active compound cannot be excluded. Changes in microcirculation may also play a role in stem cell mobilization. During the first hours after injection of high doses of endotoxin the mice are in a rather poor condition. Measurements in blood pressure and circulation through the bone marrow should be performed to further explore this possibility. With sublethal doses of histamine, adrenaline and noradrenaline no significant mobilization of stem cells has been obtained (unpublished results).

The second rise in number of circulating stem cells with its peak around the 6th-7th day after injection of endotoxin is probably due to another mechanism than the first rise. The fact that trypsin and proteinase were unable to induce this second increase already suggests 
that in these substances a structure of another nature must have been active. However, it cannot be excluded that the initial rise in number of circulating CFUs is caused by some common unknown impurity present in the three compound. The second rise must be due to another compound. Whereas for the first rise mobilization of stem cells from existing pools in the bone marrow seems the most probable mechanism, it appears more likely that the second rise is related with the proliferation of stem cells. It is a common observation that the number of CFUs in haemopoietic tissues increases during the first days after endotoxin administration (Smith et al., 1966; Hanks \& Ainsworth, 1967). McCulloch et al. (1970) provided evidence that endotoxin 'acts, via a genetically-controlled regulatory mechanism, to stimulate the proliferation of hemopoietic stem cells in the spleen'. They also found that the magnitude of the increase in the spleen is larger than in the bone marrow. Although the regulatory mechanism may be 'genetically controlled', the experiments of McCulloch et al. (1970) still do not answer the question whether endotoxin acts directly on the stem cells or via their micro-environment. The stromal factors in the haemopoietic tissues which enable circulating stem cells to 'home' and to proliferate and differentiate are determined by Trentin (cf. Trentin, 1970) as 'haemopoietic inductive microenvironments'. There may be sites with an appropriate microenvironment where stem cells can proliferate. Kretchmar (1969) has suggested that normally circulating CFU are in a state of dynamic equilibrium and lodge to proliferate whenever they pass into a site with the correct environment. From our experiments it cannot be concluded whether endotoxin injection temporarily creates more suitable sites in the spleen and bone marrow, or whether stem cells are induced to proliferate and are temporarily trapped by the spleen. With respect to this problem it is important to know the fractions of the stem cells which are in cell cycle and which are in $\mathrm{G}_{0}$-phase. Presently we are trying to elucidate this point with the ${ }^{3} \mathrm{H}-\mathrm{TdR}$ suicide technique.

It seems possible to disturb the equilibrium between circulating stem cells and stem cells lodging in their special microenvironmental sites by removing them from one of these two compartments. If these sites are emptied the haemopoietic tissue may be more avid in their capturing mechanism. When bone marrow (and thus stem cells) were intravenously injected into lethally irradiated mice their level in the blood during the first hours after injection was indeed slightly lower than when they were injected into non-irradiated mice. However, the interpretation of these results is hampered by the fact that a large percentage of the injected cells could not be retrieved from the blood or the organs investigated. When $40 \times 10^{6}$ bone marrow cells are injected about $10^{4} \mathrm{CFUs}$ are administered. From blood, liver, lung and spleen about 500,1200, 100 and 2000 of the injected CFU could be recovered. This means that about $40 \%$ of the injected CFU were found. Of the recovered CFUs $30 \%$ were not in blood or spleen. The missing CFU shortly after injection probably lodge in capillaries of other organs or remain in the bone marrow, where their number (about 10,000) in relation to the existing CFUs is too small for an easy detection. It seems reasonable to suppose that during the first hours after injection there is a continuous transfer of CFU stuck in capillaries of various organs to the circulating blood until after several hours most of them finally home in the haemopoietic tissues. This constant supply of haemopoietic stem cells to the circulation during the first hours after bone marrow injection could obscure the effect of a more rapid decrease by a greater avidity of the haemopoietic tissues in irradiated mice to capture the circulating CFUs. Kretchmar \& Conover $(1969,1971)$ estimated that between $2-4$ hr and $24 \mathrm{hr}$ after bone marrow injection, the number of stem cells present in the lung was reduced to $10 \%$, in the spleen it was reduced to $50 \%$ and in the bone marrow it increased with a 
factor of 2. Which proportions of these changes were induced by migration, proliferation or loss by differentiation is not clear from their experiments. A migration of injected bone marrow cells during the first hours after injection has been demonstrated with radioactively labelled cells by Fliedner (1960), Balner, Simmel \& Clarke (1962), Balner \& Dersjant (1964) and more recently by De Sousa (1971).

The number of CFUs we found in normal lung and liver may partly be present in the blood in those organs. However, in $1 \mathrm{ml}$ blood we found about 30-40 CFU and therefore the number in the liver seems to be too high for explanation on the basis of blood alone. It seems reasonable to expect that a few CFUs lodge more or less temporarily in the capillaries and sinussoids of the liver and possibly in other organs.

\section{Addendum}

After our paper was submitted for publication a paper by Monette et al. (1972) was published. In the latter paper proliferation and migration of haemopoietic stem cells was studied after administration of Bordetella pertussis vaccine. The authors found an increase in the level of circulating stem cells 3-7 days after injection of $20 \times 10^{9}$ killed B. pertussis organisms, but no increase on the fourth hour after injection. We only studied the effect of i.v. injected killed $B$. pertussis organisms on circulation of stem cells during the first $4 \mathrm{hr}$; $5 \times 10^{8}$ organisms had no effect and $1.5 \times 10^{10}$ increased the level only marginally (unpublished results). We did not study the effect on stem cells in blood and haemopoietic organs several days after injection, but the results of Monette et al. (1972) suggest that a similar effect is produced by killed B. pertussis vaccine as by endotoxins from S. typhos $a$ and $E$. coli. Their finding that the stem cell level in bone marrow is decreased during the period when a marked increase is observed in the spleen suggests that migration from bone marrow to spleen plays an important role. Moreover, the results obtained with hydroxyurea did not show an increase of the proliferating stem cell compartment in the spleen of a magnitude enough to explain the increase of CFU. The authors conclude that migration of stem cells from the bone marrow to the spleen would appear to be the most appropriate explanation for the increase of splenic CFU. In general Monette et al.'s results with B. pertussis are in good agreement with our findings obtained with endotoxins.

\section{ACKNOWLEDGMENT}

The authors wish to express their gratitude to Mr F. C. W. Luiten for his skilful technical assistance.

\section{REFERENCES}

Athens, J.W., HaAb, O.P., RaAb, S.O., Maver, A.M., Ashenbrucker, H., Cartwright, G.E. \& Wintrobe, M.M. (1961) Leukokinetic studies. IV. The total blood, circulating and marginal granulocyte pools and the granulocyte turnover rate in normal subjects. $J$. clin. Invest. 40, 989.

Balner, H. \& Dersjant, H. (1964) Early lymphatic regeneration in thymectomized radiation chimeras. Nature (Lond.), 204, 941.

Balner, H., Simmel, E.B. \& Clarke, D.A. (1962) Proliferation and rejection of transplanted tritium labeled bone marrow celis in mice. Transpl. Bull. 29, 427.

Barker, J.E. (1970) Embryonic mouse peripheral blood colony-forming units. Nature (Lond.), 228, 1305.

Barnes, D.W.H. \& LoLtiT, J.F. (1967a) Effects of irradiation and antigenetic stimulation on circulating haemopoietic stem cells of the mouse. Nature (Lond.), 213, 1142.

BAR.Nes, D.W.H. \& Loutr, J.F. (1967b) Haemopoietic stem cells in the peripheral blood. Lancet, ii, 1138. 
Fliedner, T.M. (1960) Die Transfusion von ${ }^{3} \mathrm{H}$ Thymidin-markierten homologen Knochenmarkzellen in ganzkörperbestrahlten Ratten. Nucl. Med. 1, 299.

Goodman, J.E. \& HodGSON, G.S. (1962) Evidence for stem cells in the peripheral blood of mice. Blood, 19, 702.

HANKs, G.E. (1964) In vivo migration of colony-forming units from shielded bone marrow in the irradiated mouse. Nature (Lond.), 203, 1393.

Hanks, G.E. \& Ainsworth, A.J. (1967) Endotoxin protection and colony-forming units. Radiat. Res. 32, 367.

HeLlman, S. (1965) Circulating stem cells: variation with duration of partial body X-irradiation. Nature (Lond.), 205, 100.

Hellman, S. \& Grate, H.E. (1968) Kinetics of circulating haemopoietic colony-forming units in the mouse. Effects of Radiation on Cellular Proliferation and Differentation, p. 187. IAEA, Vienna.

KretChmar, A.L. (1969) Comment to cover. Exp. Hemat. 19.

Kretchmar, A.L. \& Conover, W.R. (1969) Early proliferation of transplanted colony-forming cells. II. Circulation of cells. Proc. Soc. exp. Biol. (N.Y.), 131, 705.

Kretchmar, A.L. \& Conover, W.R. (1971) Colony-forming cells in the spleen. Determination of the fraction transplanted. Transplantation, 8, 576.

MCCulloch, E.A., Thompson, M.M., Siminovitch, L. \& Till, J.E. (1970) Effects of bacterial endotoxin on hemopoietic colony-forming cells in the spleens of normal mice and mice of genotype $\mathrm{S1} / \mathrm{Sl}^{\mathrm{d}}$. Cell Tissue Kinet. 3, 47.

Monette, F.C., Morse, B.S., Howard, D., Niskanen, E. \& Stohlman, F. (1972) Hemopoietic stem cell proliferation and migration following Bordetella pertussis vaccine. Cell Tissue Kinet. 5, 121.

Robinson, C.V., Commerford, S.L. \& Bateman, J.L. (1965) Evidence for the presence of stem cells in the tail of the mouse. Proc. Soc. exp. Biol. (N.Y.), 119, 222.

Smith, W.W. \& Alderman, J.M. (1962) Studies on colchicine, colchicine derivatives and endotoxin in irradiated animals. Radiat. Res. 17, 594.

Smith, W.W., Alderman, J.M. \& Cornfíeld, J. (1961) Granulocyte release by endotoxin in normal and irradiated mice. Amer. J. Physiol. 201, 396.

Smith, W.W., Brecher, G., RADD, R.A. \& Fred, S. (1966) Effects of bacterial endotoxin on the occurrence of spleen colonies in irradiated mice. Radiat. Res. 27, 369.

De Sousa, M. (1971) Kinetics of the distribution of thymus and marrow cells in the peripheral lymphoid organs of the mouse: ecotaxis. Clin. exp. Immunol. 9, 371.

TRENTIN, J.J. (1970) Influence of hematopoietic organ stroma (hematopoietic inductive microenvironments) on stem cell proliferation. Regulation of Hematopoiesis (Ed. by A. S. Gordon), Vol. 1, p. 161. AppletonCentury-Crofts, New York.

Vos, O. (1967) Radiation sensitivity and post-irradiation repair of mouse lymphatic cells in vivo and in vitro. A study with the parent to $F_{1}$ hybrid graft-versus-host reaction. Int. J. Radiat. Biol. 13, 317. 